\title{
Особенности использования земельных ресурсов в АПК и овощеводстве Российской Федерации
}

\begin{abstract}
А.Ф. Разин, Р.А. Мещерякова, О.А. Разин, Н.Н. Лебедева, Т.Н. Сурихина, Г.А. Телегина

Представлен системный анализ использования земельных ресурсов в АПК и овощеводстве Российской Федерации, выявлены факторы, негативно влияющие на развитие овощеводства. Проведенный системный анализ дает представление об использовании земельных ресурсов в АПК и овощеводстве страны, обладающей значительным потенциалом земель с.-х. назначения.

Ключевые слова: земельные ресурсы, пашня, удобрения, севооборот, АПК, овощеводство.
\end{abstract}

$\mathrm{H}$ есмотря на динамичность производства овощной продукции в открытом грунте и постепенного восстановления защищенного грунта, в российском овощеводстве сохраняется ряд системных проблем, которые ограничивают увеличение производства овощной продукции и негативно сказываются на его эффективности. Одна из серьезнейших проблем - это нерациональное использование земельных ресурсов, в том числе, пашни.

Цель работы: определить системные проблемы, сдерживающие эффективное использование земельных ресурсов, и наметить основные пути экономического воздействия направленные на обеспечение рационального использования земли, как важнейшего природного ресурса, воспроизводства и повышения почвенного плодородия.

Земля - одно из важнейших и особенных средств производства. По данным ФАО, 95-97\% продовольствия человечество получает за счет ведения агропроизводства с использованием почвенных ресурсов. Важнейшее свойство земли - почвенное плодородие. Оно обуславливает общую продуктивность биоценоза и урожайность с.- х. культур. Поэтому определяющий фактор устойчивого с. - х. производства - рациональное и эффективное использование земельных ресурсов. Что сегодня происходит с пашней?
В мировом масштабе идет постоянное сокращение пашни в расчете на душу населения. Дополнительных земель для вовлечения в хозяйственный оборот на планете не осталось. Из-за отсутствия ресурсов для ведения интенсивного с.- х. производства подвергается деградации 20\% пахотных и 10\% пастбищных земель мира. Степень распашки территорий (при предельных значениях 40\%) достигла в Китае - 75\%, Индии - 70\%, в Российской Федерации - 66\% [1, 2].

В XX веке Россия занимала четвертое место в мире по запасам земель с. - х. назначения (124 млн га пашни) после США (176 млн га), Индии (162 млн га) и Китая (143 млн га) и по наличию пахотных земель на одного жителя $(0,86$ га), после Австралии (2,40 га), Канады (1,46 га) и Аргентины $(0,89$ га). По итогам Всероссийской с.- х. переписи 2016 года в России осталось 94,641 млн га пашни. Угрожающий характер приняло загрязнение почвы, атмосферы и воды. В результате человеческой деятельности многократно усиливается естественная эрозия почвы. В Европе подвержены процессам эрозии 46\% почв. В 20072009 годах ежегодно в мире вследствие эрозии из сельхозооборота выпадало по 6-7 млн га земель, а за счет заболачивания, засоления и выщелачивания еще 1,5 млн га [2].

Для Европы наиболее распространенный вид загрязнения почвы закисление. Выпадение окислов азо- та и серы ведет к снижению $\mathrm{pH}$ почвы. В Европе засолено более 3 млн га земель. В большинстве случаев закисление замедляет рост растений, снижает биоразнообразие, ведет к опустыниванию.

Для России, помимо эрозии, характерны также засоление, заболачивание, дефляция, опустынивание, подтопление, зарастание полей мелколесьем и кустарником и другие процессы, ведущие к потере плодородия сельхозугодий и выводу пашни из с. - х. оборота. Основные причины этого - изменение климата и хозяйственная деятельность человека.

По данным государственного доклада о состоянии окружающей среды в 2007 году, в России подвержены деградации $80 \%$ с.- х. земель (в основном, эрозия). Засоление охватывает до 20\% земель, 12,3\% площадей приходится на заболачивание, 17,8\% обусловлено водной и 8,4\% ветровой эрозией. Важнейшее следствие эрозии - снижение органического вещества в почве и продуктивности экосистем, уменьшение биоразнообразия в системе «растения - микроорганизмы - почва». Установлено, что за последние 100 лет на территории России содержание гумуса в почве сократилось на 30\%. За период с 1979 по 2000 годы площадь деградированных почв увеличилась в 1,6 раза [3].

Российская Федерация обладает необходимым потенциалом для развития агропромышленного комплекса - обширные территории с плодородными почвами, богатые запасы пресной воды, территориальная близость к крупнейшим центрам потребления. В конце прошлого столетия на долю России приходилось 9\% мировой продуктивной пашни, 52\% мировых черноземных почв, 20\% запасов мировой пресной воды и 8,5\% производства минеральных удобрений [4].

Площадь земельного фонда Российской Федерации на 1 янва- 
ря 2013 года составляла 1709,8 млн га. В структуре земельного фонда России основную долю занимают земли лесного фонда (1121,9 млн га или $65,6 \%$ ) и земли с. - х. назначения (386,1 млн га или 22,6\%). Площадь сельхозугодий всех категорий земель составляет 220,2 млн га, что соответствует 12,9\% земельного фонда России. Это означает, что для занятия сельским хозяйством пригодна только восьмая часть всего земельного фонда страны.

В структуре сельхозугодий доля пашни составляла в общей ее площади 55,2\% и это был один из лучших показателей в мире. Высокая доля земель лесного фонда обеспечивает благоприятную экологическую обстановку не только в нашей стране, но и во всем мире. Вместе с тем, сложившаяся структура предполагает бережное отношение к имеющемуся фонду земель с. - х. назначения.

За годы проведения земельной реформы сложилась устойчивая тенденция снижения площади сельхозугодий, в том числе пашни (табл. 1) [5, 6].

За 10 лет, прошедших между с.х. переписями 2006 и 2016 годов, общая земельная площадь сократилась на $22,7 \%$, сельхозугодья - на $14,1 \%$, пашня - на 9,8\%. А фактически использованная площадь сельхозугодий увеличилась с 27,8\% в 2006 году до $35,9 \%$ в 2016 году.

В России с 2008 года из земель c. - х. назначения 255 млн га перешли в другие категории. Посевные площади с.- х. культур сократились с 118,4 млн га в 1986-1990 годах до 77,7 млн га в 2011-2015 годах, или на 34,4\%, за счет отчуждения и перехода в другие категории, в том числе категорию бросовых земель, также не используемых государством в с. - х. производстве. Государство при этом несет значительные финансовые потери от уменьшения налоговой базы и налоговых поступлений в результате сокращения производства с.- х. продукции. В овоще- водстве посевные площади овощных культур в хозяйствах всех категорий с 1961 года продолжают оставаться на уровне 650-690 тыс. га.

По данным академика РАН А.В. Петрикова, на 1 июля 2016 года среди личных подсобных и индивидуальных хозяйств граждан в сельских поселениях количество заброшенных земельных участков и с пустующими домами в 17 областях колебалось от 20,2\% (Тульская область) до 43\% (Сахалинская область), в Камчатском крае - 20,5\%, Республиках Коми и Алтай - по $20,1 \%$ от общего числа хозяйств. Заброшенные земельные участки граждан и бросовые земли, выключенные из оборота, в том числе плодородные, пойменные овощепригодные участки земли зарастают кустарником, идет их заболачивание. В условиях Дальнего Востока и Сибири часть неиспользуемых сельхозугодий уже заросло лесом.

На протяжении всего периода проведения реформ наблюдается зарастание сельхозугодий лесом, что связано с их невостребованностью. В отдельных регионах ежегодно фиксируется в учете добровольный отказ с.- х. организаций (CXO) и крестьянских (фермерских) хозяйств (КФХ) от предоставленных им ранее земель из-за недостатка собственных ресурсов и отсутствия мер господдержки со стороны региональных властей. Большие площади, которые числятся в собственности (аренде) КФХ, используются для несанкционированных свалок. Такое положение свидетельствует о нерациональном использовании земли в связи с бездействием региональных властей.

Мероприятия по вовлечению в оборот неиспользуемых земель проводятся постоянно, но их темпы остаются низкими

В России остается невовлеченными в оборот около 30 млн га пашни. По экспертной оценке специалистов Минсельхоза РФ, в оборот

Таблица 1. Наличие и использование земельных ресурсов в РФ, тыс. га (по итогам Всероссийской с. - х. переписи 2006 и 2016 годов)

\begin{tabular}{|l|c|c|}
\hline \multicolumn{1}{|c|}{ Показатель } & На 01.06.2006 & На 01.06.2016 \\
\hline Общая земельная плещадь & 450599,5 & 348362,8 \\
\hline из нее: сельхозугодья & 165985,1 & 142659,7 \\
\hline В том числе: пашня & 102140,0 & 94641,1 \\
\hline сенокосы & 13930,2 & 10309,5 \\
\hline пастбища & 35200,5 & 26539,4 \\
\hline залежь & 13936,1 & 10519,2 \\
\hline $\begin{array}{l}\text { Из общей площади сельхозугодий фактически } \\
\text { используется }\end{array}$ & 125480,3 & 125031,4 \\
\hline
\end{tabular}

реально можно ввести около $12 \mathrm{млн}$ га, тогда как остальная, неиспользуемая с дореформенного периода пашня, заросла лесом, поэтому она постоянно оформляется и передается в лесной фонд.

Крайне медленными темпами проходит мелиорация посевных площадей и восстановление плодородия почв. Из общей площади сельхозугодий в 2016 году фактически орошалось 55,2\% (табл. 2).

В 2012 году в стране на стадии мелиоративного строительства и восстановления плодородия почв находилось 489,7 тыс. га, при необходимости 1,5-2,0 млн га в год. Значительные площади земель орошаются в Краснодарском и Ставропольском краях, Ростовской, Астраханской и Волгоградской областях. При этом мелиоративное состояние большей части земель этих регионов характеризуется как хорошее.

Таким образом, проводимые земельные реформы пока не способствуют полному и эффективному использованию имеющегося земельного потенциала.

За годы существования Российской империи и Российской Федерации было проведено несколько земельных реформ [7, 8]. В начале 1990-х годов в России сделана очередная попытка справедливого распределения земли. Основной задачей аграрной реформы в России, проводимой с 1991 года, была приватизация земли и реорганизация колхозов и совхозов с целью формирования эффективного с.- х. производства на основе частной собственности на землю и личной предприимчивости производителей с.- х. продукции.

Принятые нормативно-правовые акты были направлены в сторону смены государственной земельной собственности на частную. В дореформенный период основными формами хозяйствования в аграрном секторе страны оставались колхозы и совхозы, число которых составляло чуть более 25 тыс. В ходе реформ 11,9 млн российских крестьян получили в собственность условные земельные паи (10-15 га на человека). Колхозы и совхозы были реорганизованы в различные организационно-правовые формы частной собственности. Из 25,8 тыс. колхозов и совхозов (1990 год) было создано 5,4 тыс. акционерных обществ, 6,7 тыс. обществ с ограниченной ответственностью, 11,6 тыс. с.- х. коо- 
Таблица 2. Наличие и использование мелиорированных земель РФ, тыс. га (по итогам Всероссийской с. - х. переписи 2006 и 2016 годов)

\section{Показатель}

Орошаемые сельхозугодья

из них фактически орошается

Осушаемые сельхозугодья

из них с фактически действующей осушительной сетью
Ha 01.06.2006

\begin{tabular}{|c|c|}
\hline 2375,1 & 1816,5 \\
\hline 939,2 & 1003,0 \\
\hline 2405,0 & 1072,6 \\
\hline 1100,4 & 667,7 \\
\hline
\end{tabular}

перативов, 3,2 тыс. государственных унитарных и муниципальных предприятий. С окончанием формирования многоукладного аграрного сектора численность землепользователей резко увеличилась.

По данным с.-x. переписи 2006 года, в аграрном секторе экономики численность землепользователей увеличилась в 16 раз и составила 58901 с. - х. организаций, в т.ч. 27781 крупных и средних, 253236 крестьянских КФХ и 31789 предпринимателей. Непосредственно занимались сельским хозяйством только 67,6\% СХО, в т.ч. 69,5\% крупных и средних, 49,3\% КФХ и 66,0\% индивидуальных предпринимателей (ИП).

По результатам с.-х. переписи 2016 года за период с 2006 по 2016 годы численность СХО уменьшилась на 22,8 тыс. (38\%), фермерских хозяйств сократилась до 136,6 тыс. (53,5\%), ЛПХ осталось 16,2 млн (снижение на 20\%), личных хозяйств осталось 3,2 млн или втрое меньше, чем в 2006 году.

Главная цель земельных преобразований в Российской Федерации состояла в обеспечении рационального использования и охраны земель как важнейшего природного ресурса, создании правовых, экономических, организационно-технологических и других условий для воспроизводства и повышения плодородия почвы, сохранения сельских, лесных и других земель, улучшения природной среды, развития сельских и городских поселений. Были сняты ограничения на развитие ЛПХ. В результате преобразований в 2006 году сформировался многоукладный аграрный сектор, состоящий из СХO, КФХ, а также ИП и ЛПХ.

Раздача земли и материальных средств производства в частную собственность в силу противоречий и не концептуальной аграрной земельной политики государства не привела к повышению деловой активности миллионов новых собственников, притоку капитала в сельское хозяйство.

Наиболее активное прекращение деятельности КФХ и ИП было за- регистрировано в 2001-2005 годах. Реформирование совхозов и колхозов привело к резкому сокращению объемов производства. Основной причиной был раздел материальнотехнической базы на имущественные паи собственников, которые в итоге привели к ресурсно-производственному кризису. При этом малым предприятиям не досталась техника, необходимая для обработки полученных земельных участков и производственные помещения, необходимые для производственной деятельности. Отсутствие в малых предприятиях необходимой техники, качественных семян, квалифицированных специалистов (агрономов, инженеров, механизаторов и др.), необходимых служб и подразделений, способных сохранить существующий технологический и технический уровень производства, привело к необходимости или отказаться от использования земли, или передать в аренду свои земельные ресурсы крупным высокоинтегрированным холдингам и агрофирмам, или присоединиться к быстро развивающимся фермерским хозяйствам. На базе средних и малых предприятий с участием инвесторов были созданы крупные агрохолдинги, которые имели финансовые и технические возможности вовлекать в оборот неиспользуемые земельные ресурсы [9].

В 1991 году новым владельцам передали права собственности на землю в количестве 213,8 млн га, в том числе 209,8 млн га СХО и 4 млн га КФХ и ЛПХ. Через 15 лет по причине вывода земель из состава c.-х. назначения, площадь сельхозугодий в СХО сократилась на $36 \%$ (до 133,6 млн га), а в фермерских хозяйствах возросла до 24,5 млн га (в 6 раз). Ослабление контроля государства над уровнем использования земель, снижение до минимума господдержки и предоставление излишней самостоятельности землевладельцам при использовании сельхозугодий привело к тому, что некоторая часть земель новыми собственниками земли не использовалась. По данным с.-х. переписи 2006 года площадь используемых земель СХО к 2006 году уменьшилась до 96,5 млн га (на 27,7\%), 23\% сельхозугодий не использовалась крупными и средними хозяйствами, 47,5\% - малыми предприятиями, 38\% - подсобными хозяйствами, 19,3\% - фермерскими хозяйствами.

Перепись 2016 года показала, что за 10 лет, прошедших от предыдущей переписи, значительно увеличились площади фактически используемых земель - в СХО с 72,3\% в 2006 году до 88,9\% в 2016 году, в КФХ и ИП - соответственно с 81,0\% до 91,7\%. При этом не имели в своей собственности земельной площади 12,2\% СХО и 17,2\% хозяйств КФХ и ИП. Размер земельной площади свыше 10 тыс. га имели 76,7\% СХО (при среднем размере на одну организацию 66512,2 га), 33,8\% КФХ и ИП имели земельную площадь от 501 до 3000 га, 30,2\% - свыше 3000 га, а 0,3\% хозяйств - до 4 га (при средней площади на одно хозяйство - 1,7 га).

В зависимости от регионального расположения СХО с земельной площадью до 3 га в их посевах преобладают картофель, овощи и бахчевые культуры.

Больше половины с.- х. продукции, включая овощную, производится в ЛПХ, хотя в последние годы прирост продукции в них снижается. При этом небольшие СХО: КФХ и ИП ведут деятельность по возделыванию монокультур, а средние и крупные хозяйства начинают использовать научно обоснованную систему земледелия, включающую в себя севообороты. Посевные и уборочные комплексы эффективно использовались только в 7,8\% средних и крупных СХО. СХО и КФХ занимаются предпринимательской деятельностью, тогда как ЛПХ развиваются в основном с целью обеспечения самозанятости и самообеспечения.

По данным Росстата в России в постперестроечный период ежегодно фактически под овощными культурами находится 660-690 тыс. га, что составляет около 0,9\% от всей посевной площади с.- х. культур в стране.

Общая динамика посевной площади овощных культур открытого грунта за период с 1945 года имеет тенденцию к снижению.

Посевные площади овощных культур в хозяйствах всех категорий сократились с 901 тыс. га в 19451950 годы до 697 тыс. га в 19811990 годы и до 662 тыс. га в 2017 году (рис.) [9, 10].

№5/2019 Картофель и овощи 
За период реформ происходит резкое снижение посевных площадей в СХО и их повышение в хозяйствах населения и появившихся КФХ. Овощные культуры занимали в 19861990 годы 669,4 тыс. га, из них 470 тыс. га (72,2\%) засевали СХО, 199,4 тыс. га $(29,8 \%)$ хозяйства населения. В 2001-2005 годы из 690,1 тыс. га СХО принадлежало 118,0 тыс. га $(17,1 \%)$, хозяйствам населения 530,2 тыс. га $(76,8 \%)$ и 41,9 тыс. га $(6,1 \%)$ КФХ и ИП. С 2006 по 2016 года удельный вес посевных площадей по категориям хозяйств изменялся незначительно, в т.ч. по СХО от $13,6 \%$ до $16,1 \%$, хозяйствам населения от $70,8 \%$ до 75,5\%, КФХ и ИП от 10,3\% до 13,5\%. При этом производство овощей увеличилось с 2015 года по 2017 год в СХО с 17,9\% до 21,2\%, в КФХ с $15,1 \%$ до 15,9\%, снизилось в хозяйствах населения с 67,0\% до $62,9 \%$ от объема производства в хозяйствах всех категорий.

Проведение аграрного реформирования сопровождалось в ряде случаев нерациональным использованием земельных ресурсов.

В целом по России под посевами задействовано $67,6 \%$ имеющейся пашни. Уровень по округам России колеблется от 64,0\% в Дальневосточном до 76,4\% в СевероКавказском округах. Нерациональное использование пашни выражается в снижении общей культуры земледелия, нарушении севооборотов, технологий возделывания. Были сокращены объемы внесения минеральных и органических удобрений, средств защиты растений от вредителей, болезней и сорняков. При решении задачи сохранения и повышения объемов производства продукции все это может привести к истощению плодородия и увеличению потребностей в материально-технических ресурсах. Однако при недостатке материально-технических ресурсов плодородие почв падает, а при увеличении техногенного воздействия почвы чрезмерно загрязняются и уплотняются. Так, к уплотнению почв ведет использование тяжелой с. -х. техники. Физическая деградация приводит к снижению пористости и проницаемости почвенных частиц, уменьшению доступа воды и кислорода к корням растений, замедлению роста растений, снижению числа доступных мест обитания для почвенных организмов, включая дождевых червей и микроорганизмов, и в конечном итоге к снижению продуктивности и биоразнообразия.

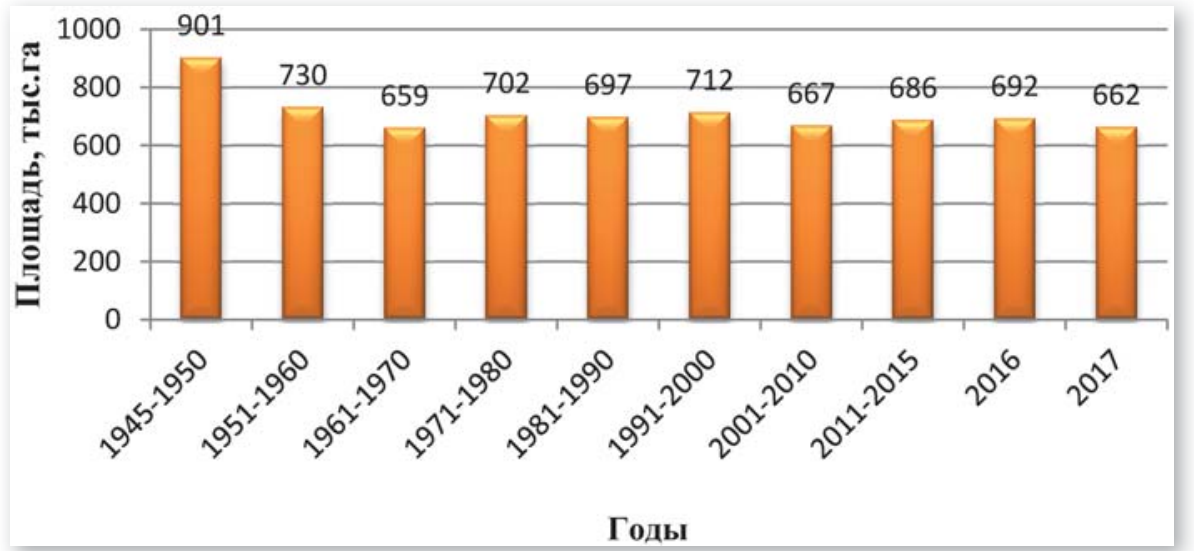

Динамика среднегодовых показателей посевной площади овощных культур в хозяйствах всех категорий, тыс. га (по данным Росстата)

Такая физическая деградация охватывает более $28 \%$ сельхозугодий европейских стран и значительные площади пашни РФ.

Оптимального решения в использовании земельных ресурсов можно достичь за счет сохранения площадей пахотных земель и приемлемых уровней интенсификации земледелия и прогрессивных технологий.

В 2000 году в мире использовалось 144 млн т минеральных удобрений. В мировом масштабе в среднем на 1 га вносилось 103 кг удобрений. За период с 1980 по 2010 годы сократили применение минеральных удобрений с 860 кг до 520 кг/га в Нидерландах, в то время как ряд стран увеличили их применение в Великобритании с 297 до 346, Израиле - с 244 до 356, Ирландии с 542 до 651, Малайзии - с 453 до 836 кг/га. Рост использования минеральных удобрений в мире грозит ухудшением экологической обстановки и опасен для окружающей среды и населения. посевы овощных культур (по данным Росстата), 2015-2017 годы

\begin{tabular}{|c|c|c|c|}
\hline \multirow{2}{*}{ Показатель } & \multicolumn{3}{|c|}{ Год } \\
\hline & 2015 & 2016 & 2017 \\
\hline $\begin{array}{l}\text { Производство минеральных или химических удобрений (в пере- } \\
\text { счете на 100\% питательных веществ), млн т, в том числе: }\end{array}$ & 20,1 & 20,8 & 22,5 \\
\hline азотные & 8,7 & 9,5 & 10,0 \\
\hline фосфорные & 3,3 & 3,6 & 3,9 \\
\hline калийные & 8,1 & 7,8 & 8,6 \\
\hline $\begin{array}{l}\text { Внесено минеральных удобрений под посевы в СХО (в пересчете } \\
\text { на 100\% питательных веществ) всего, млн т }\end{array}$ & 2,0 & 2,3 & 2,5 \\
\hline на 1 га, кг (всей посевной площади) & 42 & 49 & 55 \\
\hline овощебахчевых культур & 166 & 195 & 198 \\
\hline Внесено органических удобрений всего, млн т & 64,2 & 65,2 & 66,6 \\
\hline на 1 га, т (всей посевной площади) & 1,3 & 1,4 & 1,5 \\
\hline овощебахчевых культур & 3,6 & 2,8 & 2,6 \\
\hline
\end{tabular}

Одной из гарантий стабильного роста производства растениеводческой продукции в России может стать рациональное использование минеральных и органических удобрений, но для обеспечения с.х. культур удобрениями необходимо резко сократить их экспорт.

В рамках целевой программы «Сохранение и восстановление плодородия почв земель с.x. назначения и агроландшафтов как национального достижения России на 2006-2010 годы и на период до 2012 года» были предусмотрены мероприятия по восстановлению почвенного плодородия. Мероприятия по защите земель в рамках Госпрограммы были профинансированы полностью, а по внесению удобрений, лишь частично. Поэтому при плане 12,4 млн т было внесено 10,9 млн т, т.е. фактически по 90 кг на 1 га пашни. План по внесению минеральных удобрений в целом выполнен лишь на $88,1 \%$. Однако в дальнейшем идет 
резкое снижение этих показателей (табл. 3).

Продажа минеральных удобрений на внутреннем рынке составляет не более 23-25\% произведенных в стране. Импорт минеральных удобрений возрастает с 69,6 тыс. т в 2015 годы до 97,0 тыс. т в 2016 годы, при экспорте 15354,9 тыс. т в 2015 году и 15504 тыс. т в 2016 году.

По данным Росстата, в 1972 году на каждый га овощного поля вносилось до 1000 кг минеральных удобрений и более 15 т органических. Произошло резкое снижение вносимых минеральных удобрений с 400450 кг/га в доперестроечный период до 131 кг в 2006 году и до 198 кг в 2017 году и органических удобрений с 15 т/га в 2006 году до 2,6 т/га в 2017 году. При этом в СХО органические удобрения были внесены всего лишь на 8-9\% посевной площади. Такие объемы внесения минеральных удобрений не покрывают 40$50 \%$ выноса питательных элементов из почвы, в результате, лишенная органических и минеральных удобрений почва истощается. Ежегодный вынос питательных веществ из почвы в 4-5 раз превышает их возврат. Недостаток в первую очередь органических и минеральных удобрений приводит к развитию деградационных процессов: дегумификации, подкислению, эрозии, вторичному засолению $[10,11]$.

По данным Росстата, удельный вес посевной площади удобренной минеральными удобрениями составляет в СХО - 33,7\%, в КФХ и ИП 19,5\%. Государственный мониторинг земель РФ показал, что $46 \%$ обследованной площади характеризуется очень низким содержанием органических веществ.

Возобновление плодородия овощепригодных почв возможно выполнить только продуманным научно обоснованным сочетанием двух мероприятий - внесением удобрений и правильным севооборотом $[10,11]$.

Роль севооборота состоит прежде всего в повышении плодородия почвы за счет регулирования режима органического вещества почвы и минеральных элементов питания, поддержания удовлетворительного структурного состояния почвы; предотвращения процессов эрозии и дефляции; ограничения развития сорной растительности; регулирования фитосанитарного состояния почвы, повышения продуктивности и качества продукции с.- х., вклю- чая овощные культуры. Многолетние исследования ВНИИО совместно с овощными опытными станциями, расположенными в основных зонах товарного овощеводства, на семи почвенных разностях с содержанием гумуса от 0,6\% до 6,6\% и мощностью гумусового горизонта от 1520 см до 100-120 см, показали, что сохранение высокого плодородия почв в овощеводстве, оптимизация их питательного режима, повышение физико-химических, агрофизических и агрохимических свойств почвы возможно только при применении органо-минеральных или органо-минерально-биологических систем удобрений в овощекормовых или овощесидеральных севооборотах $[10,11]$.

Ученые и практики с.- х. производства находятся в состоянии постоянного поиска и разработки наиболее рациональных экономически приемлемых технологий производства с.- х. продукции, включая и овощную. В настоящее время разработан и внедрен в практику ряд систем альтернативного земледелия, в том числе биологического (экологического). Система земледелия предполагает правильное использование севооборотов, удобрений - органики, растительных остатков, соломы, сидератов и т.п.; естественное плодородие почв, которое позволяет решить проблему обеспечения элементами питания; улучшенное усвоение азота благодаря бобовым культурам; полный отказ от применения минеральных удобрений и ядохимикатов. Ценная и привлекательная черта биологизации - экологическая безопасность продукции, отсутствие загрязнения окружающей среды и повышение естественного плодородия почв.

Заключение. Проведенный системный анализ дает представление об использовании земельных ресурсов в АПК и овощеводстве страны, обладающей значительным потенциалом земель с.-х. назначения. Отмечено нерациональное использование земельных ресурсов, в том числе пашни. Из-за несовершенства управления земельными ресурсами и недостаточного государственного контроля за их использованием, происходит значительное выбытие земель с.- х. назначения из оборота и перевод их в другие категории. Заброшенные земельные участки граждан и бросовые земли, выключенные из оборота, зарастают кустарником, идет их заболачивание. Использование земель в монокультуре, резкое сокращение ис- пользования органических и минеральных удобрений, применение тяжелой техники приводит к снижению плодородия почв.

С точки зрения авторов, решение этих проблем возможно, в первую очередь, с участием государственных органов, с помощью государственного регулирования (мониторинга земель, землеустройства, совершенствования государственного земельного кадастра и др.) и с использованием механизмов экономического воздействия. Механизм рационального использования земельных ресурсов в АПК и овощеводстве должен быть прописан в Государственных программах и предусматривать как воспроизводство почвенного плодородия, так и обеспечение применения научно-обоснованных агротехнологий, способствующих сохранению и повышению почвенного плодородия. Оптимального решения можно достичь за счет сохранения площадей пахотных земель и приемлемых уровней интенсификации земледелия, а также прогрессивных технологий с государственной поддержкой, особенно малых форм хозяйствования.

Библиографический список

1.Тульчеев В.В., Лукин Н.Д., Ягфаров О.М. Стратегия продовольственной и национальной безопасности России в мировом экономическом пространстве в 21 столетии / под ред. И.В. Савченко. М.: Россельхозакадемия, 2013. 588 с.

2.Голубкина Н.А. и др. Глобальный экологический кризис. Проблемы и решения. М.: Изд-во ВНИИССОК, 2013. 208 с

3.Государственный национальный доклад о состоянии и использовании земель Российской Федерации в 2012 году / сост. Т.В. Фатеева, С.М. Шубич и др. М.: Петровский парк, 2012. 248 с.

4.Жученко А.А. Стратегия адаптивной интенсификации сельского хозяйства (концепция). Пущино: Научный центр РАН, 1994. 148 с.

5.Итоги Всероссийской сельскохозяйственной переписи 2006 года. Земельные ресурсы и их использование / Федеральная служба гос. статистики. М.: НИЦ "Статистика России", 2008. Т. 3. 312 с.

6.Итоги Всероссийской сельскохозяйственной переписи 2016 года. Земельные ресурсы и их использование / Федеральная служба гос. статистики. М.: НИЦ «Статистика России», 2018. Т. 3. 307 с.

7.Галишин Э.У. Развитие земельных отношений в России и в мире // Законодательство и экономика. 2012. № 5. С. $28-31$

8.Варламов А., Гальченко С. Развитие земельных отношений в России // Эксперт. 2013. № 5. С. 17-21.

9.Оксанич Н.И. Экономическая устойчивость сельскохозяйственных организаций: дисс. ... доктора экон. наук. М., 2007. 374 c

10.Литвинов С.С. Научные основы современного овощеводства. М.: Россельхозакадемия, 1998. 776 с.

11.Борисов В.А. Система удобрения овощных культур: монография. М.: Изд. ФГБНУ «Росинформагротех», 2016. 392 c. 


\section{Об авторах}

Разин Анатолий Федорович, доктор экон. наук, г.н.с. отдела экономики и прогнозов, ВНИИО - филиал ФГБНУ ФНЦО.

E-mail: 777razin@rambler.ru

Мещерякова Раиса Анатольевна, канд. с. - х. наук, с.н.с. отдела экономики и прогнозов, ВНИИО - филиал ФГБНУ ФНЦО

Разин Олег Анатольевич, канд. С. х. наук, г.н.с. селекционно-семеноводческого центра, ФГБНУ ФНЦО. E-mail: oleg.rasin@gmail.com

Лебедева Наталья Николаевна, н. с. отдела биотехнологии и инновационных проектов, ВНИИО - филиал ФГБНУ ФНЦО.

E-mail: netta.77@mail.ru

Сурихина Татьяна Николаевна, м.н.с. отдела экономики и прогнозов, ВНИИО - филиал ФГБНУ ФНЦО. E-mail: 9153756862@mail.ru Телегина Галина Алексеевна, м.н.с. отдела экономики и прогнозов, ВНИИО - филиал ФГБНУ ФНЦО

Features of use of land resources in agriculture and vegetable growing of the Russian Federation

A.F. Razin, $D S c$, chief research fellow, Department of Economics and forecasts, All-Russian Research Institute of Vegetable growing - branch of FSBSI Federal Scientific Vegetable Center (ARRIVG branch of FSBSI FSVC).

E-mail: 777razin@rambler.ru

R.A. Meshcheryakova, $P h D$, senior research fellow, Department of Economics and forecasts, ARRIVG - branch of FSBSI FSVC O.A. Razin, PhD, chief research fellow, Breeding and Seed Growing Centre, FSBSI FSVC. E-mail: oleg.rasin@gmail.com N.N. Lebedeva, research fellow,

Department of biotechnology and innovation projects, ARRIVG - branch of FSBSI FSVC

T.N. Surikhina, junior research fellow, Department of Economics and forecasts, ARRIVG - branch of FSBSI FSVC. E-mail: 9153756862@mail.ru

G.A. Telegina, junior research fellow, Department of Economics and forecasts, ARRIVG - branch of FSBSI FSVC

Summary. The system analysis of the use of land resources in agriculture and vegetable growing of the Russian Federation is presented, the factors negatively affecting the development of vegetable growing are revealed. The system analysis gives an idea of the use of land resources in agriculture and vegetable growing in the country, which has a significant potential for agricultural land.

Keywords: land resources, arable land, fertilizers, crop rotation, agro-industrial complex, vegetable growing.

\section{Улучшать угодья}

В Челябинской области появится новый вид субсидирования аграриев

По словам министра сельского хозяйства Челябинской области Алексея Кобылина, в регионе создана оптимальная система господдержки растениеводства, а также предлагаются новые виды субсидирования.

Эта информация прозвучала в ходе совещания, посвященного подготовке и организованному проведению посева овощных культур и посадке картофеля.

«Прошлый год был успешным для овощеводческих и картофелеводческих хозяйств области,- подчеркнул Алексей Кобылин.- Благоприятные погодные условия, наряду с применением новых технологий, помогли с. - х. организациям собрать значительный урожай. Картофеля собрано 148 тыс. т, овощей - 37 тыс. т. На текущий год в отрасли сохранены все виды поддержки. Они оптимальны для того, чтобы обустроить и развивать производство».

В 2019 году в Челябинской области на введение в оборот заброшенных сельхозугодий планируется 30 млн р., на приобретение минеральных удобрений 40 млн р., 200 млн р.- на покупку сельхозтехники. 35 млн р. составит несвязанная поддержка на возделывание картофеля и масличных культур, 23 млн рублей - на выращивание семенного картофеля и овощей открытого грунта. 101 млн р.- на приобретение элитных семян. В целом на развитие отрасли растениеводства в регионе предусмотрено более 10 видов господдержки.

В текущем году в Челябинской области появится новое направление субсидирования - на известкование кислых почв как важнейшего приема повышения их плодородия и увеличения урожайности. В настоящее время в Минсельхозе России разрабатывается проект правил предоставления данного вида господдержки. Планируется, что в конце апреля они будут приняты и доведены до хозяйств. Кроме того, в условиях предоставления несвязанной поддержки предусмотрен повышающий коэффициент для предприятий, проводящих известкование почв.

Предполагается, что

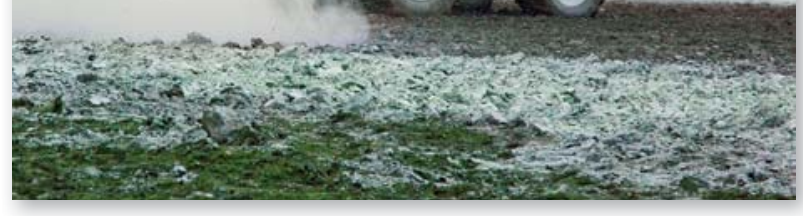
под картофелем в текущем году будет занято во всех категориях хозяйств 32,6 тыс. га. Под овощами открытого грунта планируется увеличить площади на 190 га. В целом они составят 1390 га.

По производству картофеля и овощей Челябинская область занимает 2-3 место в Уральском федеральном округе. В прошлом году в регионе был собран самый высокий урожай картофеля за последние 20 лет (с учетом хозяйств населения - 580 тыс. т). При рекомендуемой норме потребления самообеспеченность «вторым хлебом» в области составляет 189\%. За последние годы проделана большая работа по модернизации инфраструктуры хранения. Практически в каждом хозяйстве имеются современные объекты с необходимой системой вентиляции, поддержкой микроклиматических условий. В данный момент общая мощность картофеле- и овощехранилищ в регионе составляет 166 тыс. т. Этого достаточно для качественного сохранения продукции на зимний период и решения вопроса сбыта в период пиковых цен.

О нормативных требованиях к качеству семенного картофеля на совещании рассказала начальник отдела семеноводства «Россельхозцентра» по Челябинской области Олеся Широченкова. О научных разработках ЮжноУральского НИИ садоводства и картофелеводства проинформировал его директор Николай Глаз. Новые сорта овощных культур и картофеля, а также препараты, значительно повышающие их урожайность и товарность, представили сотрудники фирм-поставщиков семян и средств защиты растений. 